\title{
Genetic Variability of Natural Populations of Grapevine leafroll-associated virus 2 in Pacific Northwest Vineyards
}

\author{
Sridhar Jarugula, Olufemi J. Alabi, Robert R. Martin, and Rayapati A. Naidu
}

First, second, and fourth authors: Department of Plant Pathology, Irrigated Agriculture Research and Extension Center, Washington State University, Prosser 99350; and third author: United States Department of Agriculture-Agricultural Research Service Horticulture Crops Research Laboratory, Corvallis, OR 97330.

Accepted for publication 8 March 2010.

\begin{abstract}
Jarugula, S., Alabi, O. J., Martin, R. R., and Naidu, R. A. 2010. Genetic variability of natural populations of Grapevine leafroll-associated virus 2 in Pacific Northwest vineyards. Phytopathology 100:698-707.

Genetic variability of field populations of Grapevine leafrollassociated virus 2 (GLRaV-2) in Pacific Northwest (PNW) vineyards was characterized by sequencing the entire coat protein $(\mathrm{CP})$ and a portion of the heat-shock protein-70 homolog (HSP70h) genes. Phylogenetic analysis of CP and HSP70h nucleotide sequences obtained in this study and corresponding sequences from GenBank revealed segregation of GLRaV-2 isolates into six lineages with virus isolates from PNW distributed in 'PN', 'H4', and 'RG' lineages. An estimation of the ratio of nonsynonymous substitutions per nonsynonymous site to synonymous

substitutions per synonymous site indicated that different selection pressures may be acting on the two genomic regions encoding proteins with distinct functions. Multiple alignments of $\mathrm{CP}$ amino acid sequences showed lineage-specific differences. Enzyme-linked immunosorbent assay results indicated that GLRaV-2-specific antibodies from a commercial source are unable to reliably detect GLRaV-2 isolates in the RG lineage, thereby limiting antibody-based diagnosis of all GLRaV-2 isolates currently found in PNW vineyards. A protocol based on reversetranscription polymerase chain reaction and restriction fragment length polymorphism analysis was developed for differentiating GLRaV-2 isolates belonging to the three lineages present in the region. The taxonomic status of GLRaV-2 is discussed in light of the current knowledge of global genetic diversity of the virus.
\end{abstract}

Since its first report in California (14), grapevine leafroll disease (GLRD) has been documented in many grape-growing regions around the world $(19,27)$. Currently, GLRD is recognized as one of the most destructive diseases of wine and table grape (Vitis vinifera L.) worldwide, affecting vineyard lifespan, causing yield loss, and reducing quality attributes of berries. The economic impact of GLRD alone was estimated to be $\approx 60 \%$ of the global losses of grape production due to virus diseases (27). GLRD produces a wide range of foliar symptoms in different wine grape cultivars. These symptoms are more dramatic in red-berried than in white-berried cultivars (37). The characteristic symptoms of GLRD in red-berried cultivars include reddish-purple discolorations in interveinal areas of mature leaves near the basal part of the shoots and a narrow strip of green leaf tissue on either side of the main veins. In contrast, GLRD symptoms in white-berried cultivars are less striking, with mild to no chlorosis in the interveinal areas. In the advanced stages of the disease, however, infected leaves of both red- and white-berried cultivars show downward rolling of leaf margins, hence the name leafroll disease. In general, grapevine cultivars in the species $V$. vinifera are susceptible to GLRD and express disease symptoms, whereas many native American Vitis spp. show symptomless or latent infections.

GLRD is one of the most complex virus diseases known to infect plants. At least 10 antigenically distinct viruses called grapevine leafroll-associated viruses (GLRaVs) and numbered sequentially (GLRaV-1, -2, -3, and so on) in order of their dis-

Corresponding author: R. A. Naidu; E-mail address: naidu@wsu.edu

* The $\boldsymbol{e}$-Xtra logo stands for "electronic extra" and indicates that the online version contains four supplementary tables not available in the print version.

doi:10.1094/PHYTO-100-7-0698

(C) 2010 The American Phytopathological Society covery have been documented thus far in grapevines (28). GLRaVs belong to the family Closteroviridae (21), with the majority of them (GLRaV-1, -3, -4, -5, -6, and -9) belonging to the genus Ampelovirus, whereas GLRaV-2 belongs to the genus Closterovirus. GLRaV-7 has not yet been assigned to any of the genera in the family Closteroviridae and GLRaV-8 is considered an erroneously established or invalid virus species (11). Thus, unlike other perennial crops, grapevines can be infected with a heterogeneous group of closteroviruses, ranging from a small genome size of 13,696 nucleotides (nt) with relatively simple genome organization encoding seven open reading frames (ORFs) (25) to a large genome size $(18,498 \mathrm{nt})$ with complex genome organization encoding 13 ORFs (26). Based on phylogenetic analysis of the coat protein (CP) and partial 70-kDa heat-shock protein homolog (HSP70h) sequences, grapevine-infecting members of the genus Ampelovirus were further separated into two different subgroups (I and II), with GLRaV-1 and -3 forming one group and the others forming a second group (25). Some of these GLRaVs have been shown to be spread by different species of mealybugs and scale insects $(16,42)$; vectors for other GLRaVs are yet to be documented.

GLRaV-2 is distinct from other grapevine-infecting closteroviruses. The flexuous, filamentous particles of the virus are 1,400 to $1,800 \mathrm{~nm}$ long and its single-stranded, positive-sense RNA genome is $\approx 16.5 \mathrm{~kb}$ in size, coding for nine ORFs (Fig. 1) $(24,31,47)$. The genome organization is more similar to that of Beet yellows virus in the genus Closterovirus than it is to the members of the genus Ampelovirus (21). The biological vector for GLRaV-2 is unknown, although other members of the genus Closterovirus are transmitted by aphids (21). Thus, the virus is only known to spread by vegetative propagation of infected planting material and through grafting. However, some isolates of GLRaV-2 are mechanically transmissible, albeit inefficiently, to herbaceous hosts like Nicotiana benthamiana (17). Since its first 
identification by serological methods (20), several biological and molecular variants of GLRaV-2 have been documented in different grape-growing regions $(1,5,7,9,17,31,36,39,46,47)$. Only a few of these variants have been completely sequenced to analyze the overall genome organization of GLRaV-2: 'BD' isolate from Italy (DQ286725), 'RG' isolate from California (NC_004724), '93/955' isolate from South Africa (NC_007448), 'Pinot Noir' isolate from New York (AF039204), and 'OR1' isolate from Oregon (FJ436234). Additionally, partial genomic sequences have been generated for many GLRaV-2 isolates collected from several geographical locations and deposited in public data bases $(8,13)$. In addition to inducing GLRD-like symptoms, some of them have been implicated in other serious grapevine disorders such as graft incompatibility syndrome $(9,18)$, young vine decline $(15)$, and rootstock stem lesion disease (44). A variety of methods have been developed for the detection of GLRaV-2 variants from different grapevine accessions originating from distinct viticultural regions, including biological indexing and serological and molecular assays $(5,6,8,13,33,34)$. Due to the wide range of biological properties and molecular heterogeneity of GLRaV-2 in different grape-growing regions, an assessment of genetic variability in a given viticultural region is essential for reliable detection of all the variants of GLRaV-2 (6).

Similar to other regions, the wine grape industry in the Pacific Northwest (PNW) states of the United States of America is vulnerable to GLRD (37). A wide range of wine grape cultivars are grown in the PNW and different viticultural practices are employed for grapevine cultivation in the region. For example, wine grape cultivars are largely grown as own-rooted grapevines in Washington and Idaho and on specific rootstocks in Oregon vineyards (2). As a consequence, symptoms induced by variants of GLRaV-2 might show differences in own-rooted grapevines as opposed to the symptoms in grapevines grafted onto a specific rootstock. Although GLRaV-2 has been documented in the PNW vineyards $(30,32)$, detailed assessment of the molecular diversity of field isolates of the virus in the region would provide a foun- dation for evaluating their role in the epidemiology of GLRD. For this purpose, nucleotide sequences of the CP and HSP70h of several field isolates of GLRaV-2 were determined and compared with corresponding sequences of previously studied virus isolates from other grape-growing regions. A phylogenetic analysis revealed the presence of molecularly divergent isolates of GLRaV-2 in the PNW vineyards. By examining the ratio of synonymous (silent, $d S$ ) and nonsynonymous (amino acidaltering, $d N$ ) substitutions per site, diversifying selection acting on the two virus-encoded genes with distinct functions was evaluated. The practical utility of these results was assessed by developing a reverse-transcription polymerase chain reaction (RTPCR)-based restriction fragment length polymorphism (RFLP) protocol to distinguish GLRaV-2 variants documented to date in the region.

\section{MATERIALS AND METHODS}

Virus isolates. A list of GLRaV-2 isolates used in this study is provided in Supplementary Table 1. These isolates were obtained from different wine grape cultivars during disease surveys conducted from 2005 to 2008 in the PNW region. The virus derived from a single grapevine was considered as one isolate. The majority of the GLRaV-2 isolates were obtained from Washington vineyards. In the case of red-berried cultivars, virus isolates came from grapevines showing symptoms of, or suspected to be infected with, GLRD (37). Because white-berried cultivars do not exhibit dramatic GLRD symptoms similar to those in red-berried cultivars, the virus isolates came from grapevines suspected to have GLRD. In all cases, leaf samples were collected from different canes of the grapevine and pooled for extractions to minimize possible variations due to irregular distribution of virus in infected tissues.

Sample extraction. Extractions were made from $250 \mathrm{mg}$ of petiole samples derived from individual grapevines with the aid of a HOMEX 6 homogenizer (Bioreba AG, Reinach BL1, Switzer-

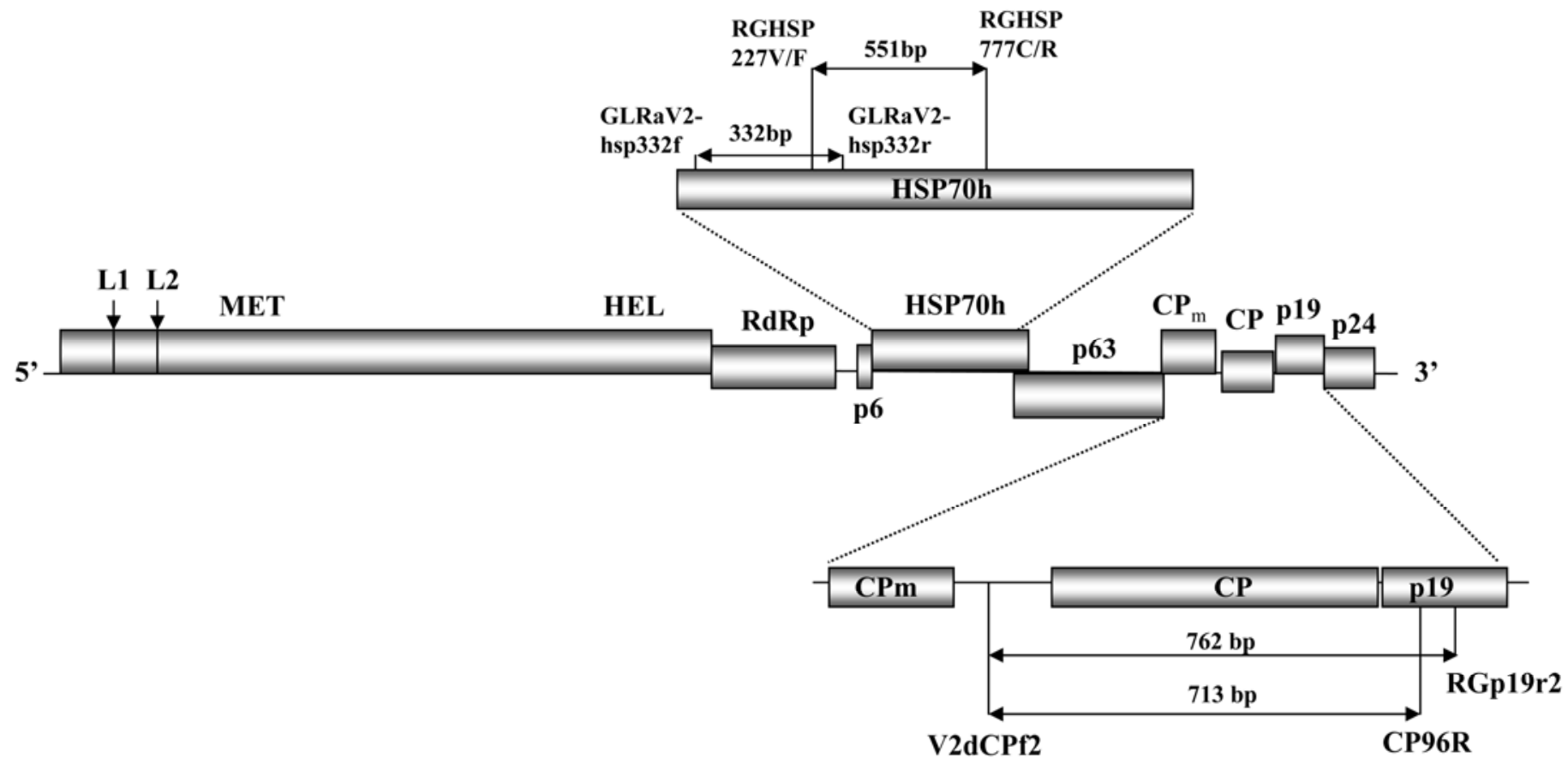

Fig. 1. Diagrammatic representation of the Grapevine leafroll-associated virus 2 (GLRaV-2) genome showing the positions of different open reading frames (open boxes) and their putative protein products. L1 and L2, leader proteases; MET, HEL, and POL, methyltransferase, RNA helicase, and RNA polymerase domains, respectively, of replicase polyprotein; p6, 6-kDa movement protein; HSP70h, 70-kDa heat-shock protein homolog; p63, 63-kDa protein; CPm, minor capsid protein; CP, major capsid protein; p19, 19-kDa protein; p24, 24-kDa protein. Locations and names of primers (described by Bertazzon and Angelini [6]) used in reverse-transcription polymerase chain reaction and the expected size (bp) of amplified DNA fragments (horizontal line with arrows) are shown for HSP70h (above genome map) and $\mathrm{CP}$ (below genome map). 
land) using the procedure described earlier (39). The extracts were used either immediately or stored at $-80^{\circ} \mathrm{C}$ for subsequent use.

Primers. Primers to amplify a portion of HSP70h and the entire CP were synthesized based on primer sequences designed and evaluated by Bertazzon and Angelini (6) and Osman et al. (34). The locations of these primers in the virus genome and the expected sizes of amplicons are shown in Figure 1. For GLRaV-2, the primer pair GLRaV2-hsp332f (5'-ATAATTCGGCGTACAT CCCCACTT-3') and GLRaV2-hsp332r (5'-GCCCTCCGCGC AACTAATGACAG-3') was selected to amplify a 332-bp fragment specific to $\mathrm{HSP} 70 \mathrm{~h}$ and the primer pair V2dCPf2 $\left(5^{\prime}-\right.$ ACGGTGTGCTATAGTGCGTG-3') and CP96R (5'-CAGATT CGTGCGTAGCAGTA-3') to amplify a 713 to 716 bp fragment covering the entire CP and flanking sequences. For GLRaV-2-RG, the primer pair RGHSP227V/F (5'-GCGACTCCAGCAACTTT AGTGA-3') and RGHSP777C/R (5' GTCTAACGAAAGATCGG GTTCTAAG-3') was selected to amplify a 551-bp fragment specific to HSP70h and the primer pair V2dCPf2 and RGp19r2 (5'-AGACTTGACGACTAGTAATG-3') to amplify a 762-bp fragment covering the entire $\mathrm{CP}$ and flanking sequences.

RT-PCR, cloning, and sequencing. The extracts were denatured (2) and used for one-tube single-step RT-PCR assay to amplify DNA fragments specific to HSP70h and CP of different GLRaV-2 isolates. The denatured extract $(2 \mu \mathrm{l})$ was added to a $25-\mu$ final volume of RT-PCR cocktail containing $1 \times$ concentration of reaction buffer consisting $1 \mathrm{mM} \mathrm{Mg}^{2+}, 0.2 \mathrm{mM}$ each dNTP per microliter, and 1.25 U of Taq DNA polymerase (from Roche Diagnostics $\mathrm{GmbH}$, Mannheim, Germany); and $1 \mu \mathrm{M}$ each of gene-specific primers, $5 \mathrm{mM}$ dithiotheitol, $4 \mathrm{U}$ of RNaseout, and 7 U of Superscript II reverse transcriptase (from Invitrogen Corp., Carlsbad, CA). RT-PCR was carried out using a thermal cycler (GeneAmp PCR systems 9700; Applied Biosystems) to amplify HSP70h- and CP-specific DNA fragments using the following conditions: RT at $52^{\circ} \mathrm{C}$ for $60 \mathrm{~min}$ followed by denaturation for $1 \mathrm{~min}$ at $94^{\circ} \mathrm{C} ; 35$ cycles of PCR, with each cycle at $94^{\circ} \mathrm{C}$ for $30 \mathrm{~s}$, $55^{\circ} \mathrm{C}$ (HSP70h) or $52^{\circ} \mathrm{C}(\mathrm{CP})$ for $40 \mathrm{~s}$, and $72^{\circ} \mathrm{C}$ for $60 \mathrm{~s}$; and a final extension at $72^{\circ} \mathrm{C}$ for $7 \mathrm{~min}$. An aliquot of the RT-PCR assay product was resolved on $1.5 \%$ agarose gels and stained with ethidium bromide, and the DNA bands were visualized under a UV-transilluminator (Biorad Universal Hood, Bio-Rad Laboratories).

The amplicons were cloned individually into pCR2.1 vector (Invitrogen Corp.), three independent clones were sequenced in both orientations, and a consensus sequence was obtained for each isolate. Additional clones were sequenced for each isolate only when sequence differences between the three clones were $>2 \%$. Nucleotide and predicted amino acid sequences were aligned and edited, and sequence identities were determined using Vector NTI Advance11 software (Invitrogen Corp.).

Sequence analysis. The accession numbers of GLRaV-2 sequences generated in this study and those obtained from GenBank are listed in Supplementary Tables 1 and 2, respectively. Multiple sequence alignments for $\mathrm{CP}$ and $\mathrm{HSP70h}$ sequences were performed using ClustalX with the default parameters. Neighbor-joining (NJ) and maximum-likelihood (ML) phylogenetic trees were constructed by the MEGA 4 software package (23) using nucleotide sequence of the entire $\mathrm{CP}$ gene and a portion of the HSP70h of GLRaV-2 genome. Bootstrap values were determined from 1,000 replicates to determine robustness of observed phylogenetic grouping, and branches with $<70 \%$ bootstrap support were collapsed. Both trees were rooted using corresponding sequences of Beet yellows virus (BYV) (GenBank accession number AF056575).

Estimation of selection pressure. Gene and site-specific selection pressures over the entire alignment of data set for $\mathrm{CP}$ and HSP70h were analyzed using the Datamonkey online positive selection interface (22) (http://www.datamonkey.org/). The ratio of nonsynonymous substitutions per nonsynonymous site $\left(d_{N}\right)$ to synonymous substitutions per synonymous site $\left(d_{S}\right)$, which is an indicator of natural selection, was calculated using three methods for detecting sites under selection: single-likelihood ancestor counting (SLAC), random effects likelihood (REL), and fixed effects likelihood (FEL). All three methods incorporate a general model of codon substitution, which rules out spurious results based on biased nucleotide frequencies (22). Depending on $d_{N} / d_{S}$ values, the selection pressure was considered negative or purifying $\left(d_{N} / d_{S}<1\right)$, neutral $\left(d_{N} / d_{S}=1\right)$, or diversifying or positive $\left(d_{N} / d_{S}>1\right)$ for the CP and HSP70h data sets.

Serology. A double-antibody sandwich enzyme-linked immunosorbent assay (DAS-ELISA) was used to test petiole samples in duplicate wells for the detection of GLRaV-2 isolates using a commercial ELISA kit (Bioreba AG). An equal amount of tissue from each sample was ground in extraction buffer and processed for DAS-ELISA testing according to the manufacturer's instructions. Samples with an average absorbance at $405 \mathrm{~nm}\left(\mathrm{~A}_{405}\right)$ value at least three times that of healthy negative control were considered to be virus positive.

RT-PCR-based RFLP typing of GLRaV-2 isolates. The CP sequences obtained in this study were used to identify unique recognition sites of restriction enzymes using the NEBcutter V2.0 program (New England Biolabs). CP-specific amplicons were then subjected to enzyme digestion using restriction enzymes Sau3A1 (Promega Corp.) and HindIII (New England Biolabs) according to the manufacturer's instructions. The DNA fragments were resolved on $1.8 \%$ agarose gels and visualized as described above.

\section{RESULTS}

RT-PCR amplification of GLRaV-2 genomic segments. In previous studies $(6,33,34)$, several primer pairs were evaluated in RT-PCR for the detection of a broad spectrum of GLRaV-2 isolates from a wide range of cultivars originating from different geographical locations. In initial studies, we evaluated these primers in different combinations for their ability to amplify sequences specific to GLRaV-2 isolates collected from wine grape cultivars in the PNW. Based on the results, four pairs of primers (Fig. 1) were found suitable for RT-PCR amplification of two distinct genomic segments of GLRaV-2 isolates documented to date in the PNW vineyard blocks. Previously, these primer pairs were shown to be capable of detecting all or at least the majority of diverse isolates of GLRaV-2 (6,34).

The primer pair GLRaV2-hsp332F and GLRaV2-hsp332R, specific to HSP70h of GLRaV-2, amplified a 332 bp fragment; and the primer pair RGHSP227V/F and RGHSP777C/R, specific to HSP70h of GLRaV-2-RG, amplified a fragment of $\approx 551 \mathrm{bp}$. The primer pair V2dCPf2 and CP96R amplified DNA fragments specific to GLRaV-2 isolates encompassing a 597 nt CP ORF, a 63 to $66 \mathrm{nt}$ intergenic region upstream of the $\mathrm{CP}$, and a $53 \mathrm{nt}$ portion of p19 ORF, downstream of the CP (Fig. 2A). The primer pair V2dCPf2 and RGp19r2 amplified DNA fragments specific to GLRaV-2-RG encompassing a $597 \mathrm{nt} \mathrm{CP}$, an $85 \mathrm{nt}$ intergenic region upstream of the $\mathrm{CP}$, and an $80 \mathrm{nt}$ portion of p19 ORF, downstream of the CP (Fig. 2B). The amplicons were found to be specific to respective isolates based on cloning and subsequent sequence analysis, as described below. In some cases, the primer pair V2dCPf2 and RGp19r2 amplified two bands of smaller-thanexpected size (Fig. 2B). However, these bands were found to be nonspecific, because their nucleotide sequences did not match with either GLRaV-2 or GLRaV-2-RG sequences (data not shown).

Documentation of GLRaV-2 isolates in PNW vineyards. Among 1,350 samples collected from different wine grape cultivars planted in 35 vineyard blocks, 97 and 10 were identified as positive for GLRaV-2 and GLRaV-2-RG, respectively, using 
the HSP70h-specific primers.. Cultivar-specific results showed that 44/302 samples from Cabernet Sauvignon (CS), 32/198 from Pinot Noir (PN), 10/192 from Merlot (MR), 5/219 from Chardonnay $(\mathrm{CH})$, and 6/10 from Sangiovese (San) were positive for GLRaV-2; and 3/198 from PN and 6/219 from $\mathrm{CH}$ were positive for GLRaV-2-RG. In addition, one sample from cv. Kashishi, a table grape cultivar, tested positive for GLRaV-2-RG. Among the 97 samples tested positive for GLRaV-2, only 1 sample from PN also tested positive for GLRaV-2-RG. None of the samples from other cultivars tested positive for GLRaV-2 or GLRaV-2-RG, indicating that these two variants did not occur as single or mixed infections in grapevine samples tested in this study. These results showed $100 \%$ consensus with the data obtained using CP-specific primers V2dCPf2 and CP96R for GLRaV-2 and V2dCPf2 and RGp19r2 for GLRaV-2-RG. None of the samples tested positive using primers specific to the $\mathrm{BD}$ variant of GLRaV-2, indicating its absence in the PNW vineyard blocks monitored to date (data not shown).

GLRaV-2 isolates from the PNW compose three major genetic lineages. The 332-nt sequence fragment from the HSP70h gene was cloned and sequenced for 63 representative isolates of GLRaV-2 and 5 representative isolates of GLRaV-2-RG from different cultivars. In pairwise comparisons, HSP70h sequences derived from three independent clones for each of the isolates showed $>99 \%$ intraisolate identity, suggesting a lack of significant genetic diversity within isolates. The phylogenetic relationships of GRLaV-2 isolates from PNW were assessed among themselves and with corresponding sequences from other grapegrowing regions. This analysis, using ML and NJ methods with the HSP70h sequence of BYV as an outgroup, included a total of 124 sequences, 68 from PNW (this work) and 56 from other geographic regions (GenBank). Global HSP70h sequences of GLRaV-2 segregated into six lineages (Fig. 3A). Each of these lineages was assigned a reference isolate to maintain a standardized nomenclature of GLRaV-2 sequence variant groups in concurrence with previous reports $(13,31)$. The robustness of the phylogenetic tree was supported by bootstrap values $>70 \%$ at each node. All GLRaV-2 sequences from the PNW were placed in $\mathrm{PN}$, 'H4', and RG lineages, suggesting their polyphyletic origin. However, a greater number of sequences (39/68) from the region were found in the PN lineage followed by the $\mathrm{H} 4$ lineage. GLRaV-2 isolates from PNW in the $\mathrm{H} 4$ lineage segregated into two sublineages (Fig. 3A). The range of nucleotide sequence identities between different lineages is shown in Table 1. Interlineage sequence identities between PN, 93/955, and H4 lineages were 83 to $86 \%$ and between 'PV20', BD, and RG lineages were 68 to $80 \%$. A similar low level of interlineage sequence identity (69 to 77\%) was also apparent when PN, 93/955, and H4 were compared with PV20, BD, and RG lineages.

In total, 42 GLRaV-2 sequences, including 19 from PNW vineyards representing 6 from the PN lineage, 8 from the $\mathrm{H} 4$ lineage, 5 from the RG lineage, and 23 from elsewhere (GenBank), were used for global phylogenetic analysis of CP sequences. The topology of the CP-based phylogenetic tree (Fig. 3B) was similar to the tree based on HSP70h sequences (Fig. 3A), with all GLRaV-2 isolates from the PNW aligning with PN, H4, and RG lineages. CP-based interlineage nucleotide sequence identities (Table 1) are in agreement with HSP70h-based values, providing additional support for separation of all currently documented GLRaV-2 isolates into six lineages.

The phylogenetic groupings of global isolates of GLRaV-2 were similar, regardless of whether they were derived from nucleotide or amino acid sequences of HSP70h or CP and whether they had been generated using distance, parsimony, or ML methods (data not shown), further supporting the robustness of our phylogenetic analysis.

Selection constraints on CP and HSP70h. The global $d_{N} / d_{S}$ ratio was computed separately for $\mathrm{CP}$ and HSP70h (Table 2) to estimate the degree of selective constraints on each genomic region. The $d_{N} / d_{S}$ ratio for individual lineages was not estimated due to the lack of a sufficient number of sequences in some of the lineages. Although this ratio was below unity for both coding regions, it varied considerably between the two regions, with a mean $d_{N} / d_{S}$ ratio of 0.081 for the CP and 0.873 for the HSP70h. These results suggest that, although both coding regions were under a predominance of negative (or purifying) rather than positive (diversifying) selection, this constraint is much higher for the CP than for the HSP70h, indicating different evolutionary constrains on these two genes. The fact that the $\mathrm{CP}$ was subjected to relatively strong selection constraints is supported by the observation that a large proportion of codon sites (138/198, or $\approx 70 \%$ ) across the entire gene were under negative selection (Table 2; Supplementary Table S3). In contrast, four codon sites were found to be under positive selection (nearly 4\%) and three codon sites (nearly 3\%) under negative selection in the analyzed HSP70h fragment (Table 2; Supplementary Table S4). Thus, it can be concluded from these results that CP and HSP70h showed contrasting patterns of evolution, with more codon sites in $\mathrm{CP}$ subjected to purifying selection (functional constraints) than those in HSP70h.
A V2dCPf2 \& CP96R

B V2dCPf2 \& RGp19r2

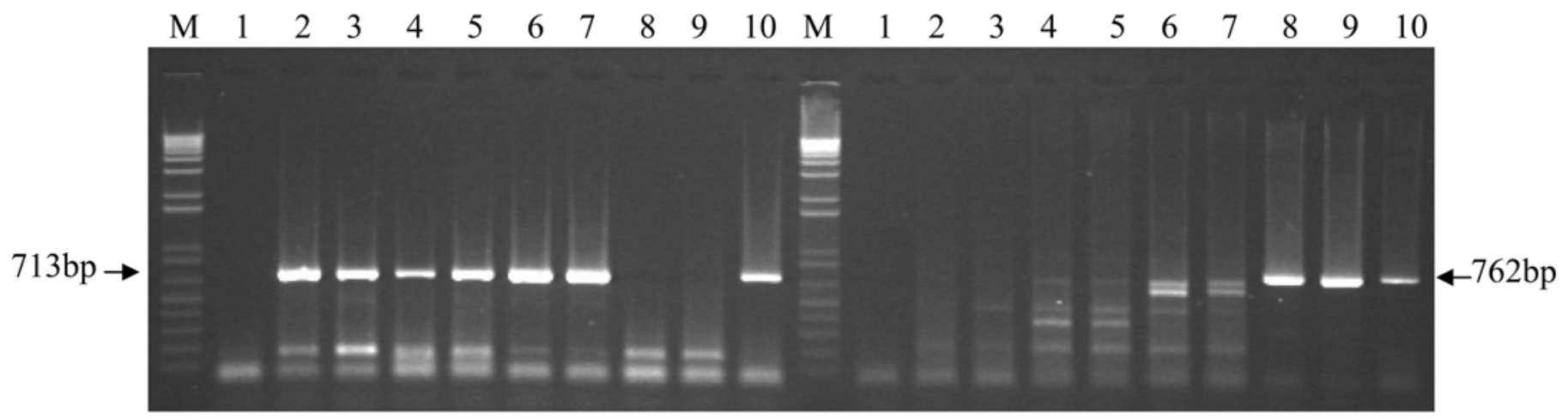

Fig. 2. Specificity of primers for amplification of coat protein (CP) sequences of A, Grapevine leafroll-associated virus 2 (GLRaV-2) (lanes 2 to 7 ) and $\mathbf{B}$, GLRaV-2-RG (lanes 8 to 9) isolates from grapevine samples. Lane M shows 1-kb-plus DNA marker (Invitrogen) for estimating the size of amplified DNA fragment. Lane 1, negative control (sample previously tested negative for each primer pair); lanes 2 and 3, isolates from 'PN' lineage; lanes 4 to 7, isolates from 'H4' lineage; lanes 8 and 9, isolates from 'RG' lineage, and lane 10, positive control (sample previously tested positive for respective primer pair). The expected size DNA band is marked with an arrow for GLRaV-2 (left) and GLRaV-2-RG (right) isolates. 
Multiple alignment of CP sequences of GLRaV-2 isolates show lineage-specific differences. In a previous study (31), multiple alignments of deduced CP amino acid sequences of four GLRaV-2 isolates showed variability in the N-terminal portion whereas their C-terminal portions were highly similar. Due to the low number of isolates used in that study, we verified this observation by aligning a total of 42 full-length $\mathrm{CP}$ sequences19 from PNW vineyards (this work) and 23 from elsewhere, currently available in GenBank. The multiple alignments of these sequences (Fig. 4) showed distinct differences in the CP sequences between isolates belonging to different lineages. In comparison with $\mathrm{CP}$ sequences of isolates belonging to the $\mathrm{PN}$ lineage, isolates belonging to 93/955 and H4 lineages showed more differences in the N-terminal portion of their CP. In contrast, most of the amino acid changes in isolates belonging to the RG lineage were localized in the central core region of the CP. On the other hand, the amino acid changes in isolates belonging to $\mathrm{BD}$ and PV20 lineages were dispersed across the entire CP gene. Based on these results, it can be concluded that, in contrast to an earlier report (31), a lineage-specific pattern of amino acid changes could be discerned in the $\mathrm{CP}$ sequences of global isolates of GLRaV-2.

Serological properties of GLRaV-2 isolates. Extracts from cambial scrapings of PNW isolates belonging to the three lineages of GLRaV-2 (PN, $n=17$; H4, $n=9$; and RG, $n=4$ ) were tested by DAS-ELISA. All GLRaV-2 isolates belonging to PN and $\mathrm{H} 4$ lineages showed a positive reaction with GLRaV-2 antibodies obtained from one commercial source, and the average $\mathrm{A}_{405}$ values were 0.58 to 2.40 , with three samples in PN lineage showing an $\mathrm{A}_{405}$ value of 3.0 to 4.0. In contrast, extracts from isolates belonging to the $\mathrm{RG}$ lineage showed an $\mathrm{A}_{405}$ value (0.09) similar to healthy controls $(0.08)$. These results indicate that RG isolates of GLRaV-2 are serologically distinct from isolates in lineages PN and H4. The results also support previous reports that
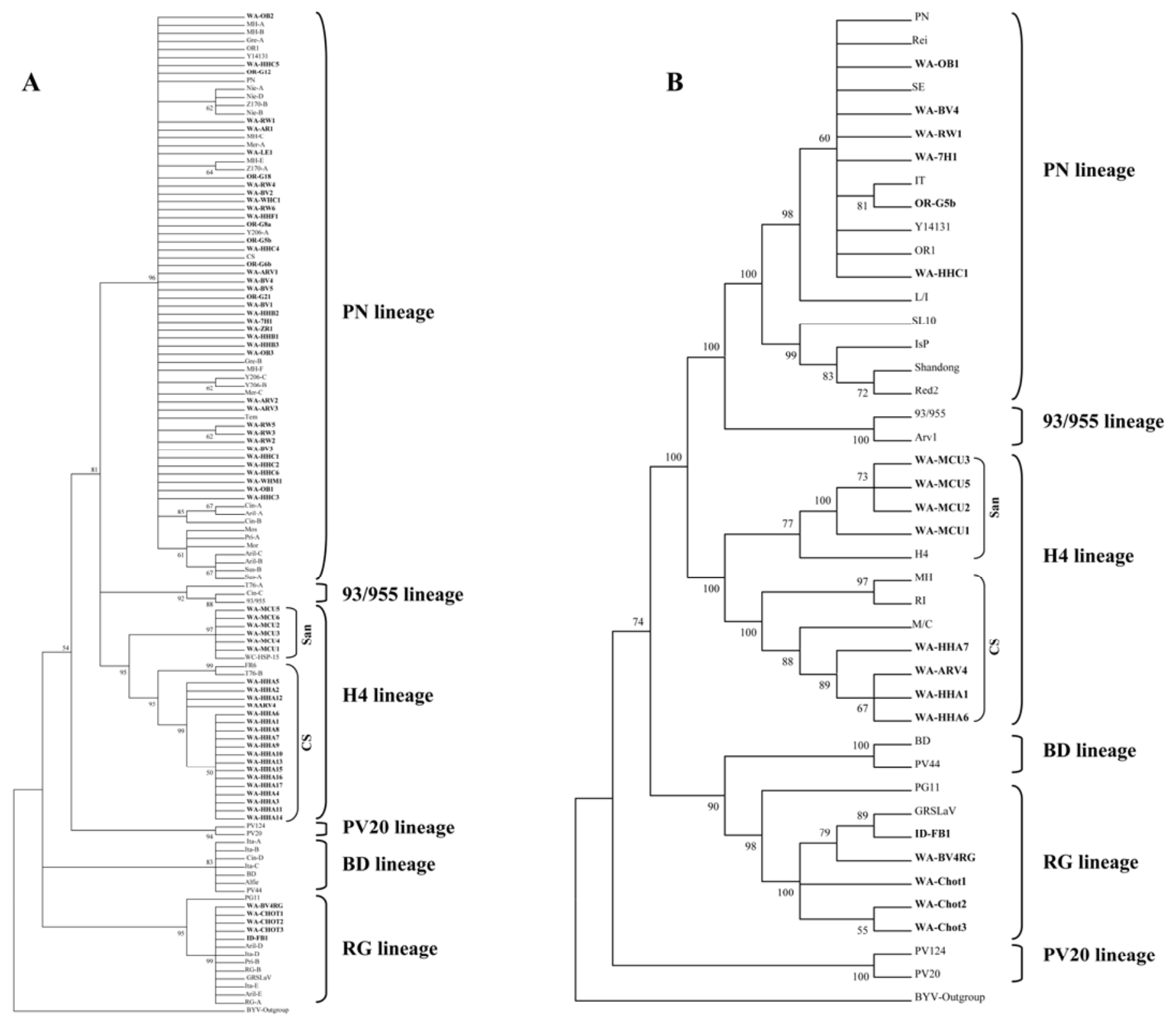

Fig. 3. Phylogenetic analysis of Grapevine leafroll-associated virus 2 (GLRaV-2) isolates based on A, 70-kDa heat-shock protein homolog (HSP70h) and $\mathbf{B}$, coat protein (CP) sequences. Trees were constructed by the maximum-likelihood method using the neighbor-joining algorithm with the Kimura two-parameter model implemented by MEGA4. Details of sequences of GLRaV-2 isolates used for construction of these trees are given in Supplementary Tables 1 and 2. Trees were rooted by using Beet yellows virus sequences as outgroup. Bootstrap values (1,000 replicates) are given at the branch nodes. Branches corresponding to partitions reproduced in $<50 \%$ of bootstrap replicates are collapsed. Optimal trees with the sums of branch length (2.03681006 for HR and 2.58111728 for CP) are shown. GLRaV-2 isolates from the Pacific Northwest are in bold. 
the RG isolate of GLRaV-2 is serologically distantly related to other GLRaV-2 isolates (4). Taken together, these results indicate that serological assays using antibodies from one commercial source may not be reliable for the detection of all GLRaV-2 isolates documented in PNW vineyards.

RT-PCR-based RFLP protocol to differentiate isolates of GLRaV-2. Based on the serological data described above, the potential of a molecular typing method based on RT-PCR-RFLP profiles was assessed for the discrimination of serologically distinct GLRaV-2 isolates documented in PNW vineyards. Following an in silico analysis of the CP sequences of GLRaV-2 isolates from PNW, two restriction enzymes, Sau3A1 and HindIII, were used to assess RFLP profiles of virus isolates from the region. The DNA fragments amplified with primer pair V2dCPf2 and CP96R for GLRaV-2 isolates and the primer pair V2dCPf2 and RGp19r2 for GLRaV-2-RG isolates were digested individually with Sau3A1 and HindIII and resolved by agarose gel electrophoresis. The two enzymes gave unique restriction patterns for distinguishing these isolates into four groups (Fig. 5). Sau3A1 digestion resulted in two fragments of 352 and 410 bp for GLRaV-2-RG isolates, whereas isolates belonging to $\mathrm{PN}$ were not digested due to lack of restriction site for Sau3A1. On the other hand, isolates belonging to the H4 lineage gave two RFLP patterns: 208 and $505 \mathrm{bp}$ for isolates in the H4-Cs sublineage and 332 and $381 \mathrm{bp}$ for isolates in the H4-San sublineage. Conversely, the HindIII digestion resulted in two fragments of 142 and $574 \mathrm{bp}$ for isolates in the PN lineage, whereas isolates in other lineages remained uncut due to the absence of this restriction site in those sequences.

\section{DISCUSSION}

In this study, genetic diversity of field isolates of GLRaV-2 collected from different vineyards in the PNW region was established using nucleotide sequences of the $\mathrm{CP}$ and a portion of HSP70h. Because GLRaV-2 sequences from the region were not included in previous studies $(6,13,31)$, this study represents the first comprehensive assessment of genetic diversity of GLRaV-2 in one of the major grape-growing regions of the United States. A comparative phylogenetic analysis of GLRaV-2 sequences from the PNW relative to sequences from other grape-growing regions within and outside the United States $(5,6,13,31)$ provided an updated global assessment of molecular variability in two genomic regions of the virus encoding proteins with distinct functions. Collectively with a recent report (13), the phylogenetic analysis of GLRaV-2 conducted in this study supports segregation of GLRaV-2 isolates into six lineages (Fig. 3). However, it seemed appropriate to use the entire $\mathrm{CP}$ gene sequences as the best representation of the phylogeny of GLRaV-2 lineages, because CP-based phylogeny has been used for classifying several different groups of viruses and their strains (12).

The results showed that GLRaV-2 isolates from PNW aligned only with the PN, H4, and RG lineages, and their overall relationships with isolates from other regions were similar whether the phylogenetic trees were constructed from HSP70h or CP sequences (Fig. 3). Although the majority of GLRaV-2 from PNW clustered within the PN clade, consisting of isolates from Brazil, Italy, the People's Republic of China, South Africa, and the United States, close sequence relatedness of other isolates with those in the H4 lineage from Brazil and the United States, and a few isolates with those in the RG lineage from the United States and Italy, suggested lack of clustering by geographical origin. Such a situation seems not surprising for a vegetatively propagated crop, and could be due to the introduction of contaminated planting materials from different external sources and subsequent local dissemination of planting materials via multiple sources (43), in contrast to geographical delineation of virus variants in some vector-borne viruses $(41,45)$. Lack of a biological vector for GLRaV-2 provides additional evidence in support of this argument.

The RG strain of GLRaV-2 has, thus far, been documented only in table grape cultivars, although different wine grape cultivars have been subjected to testing in Italy $(4,38,39)$. In contrast, we have detected the RG strain of GLRaV-2 in two wine grape cultivars (Pinot Noir and Chardonnay) and one table grape cultivar (Kashishi) grown in three geographically separate vineyard blocks. To the best of our knowledge, this study represents the first confirmed report of the occurrence of GLRaV-2-RG in wine grape cultivars and underscores the importance of indexing wine grape cultivars for this variant in quarantine, certification, and clean plant programs.

GLRaV-2 isolates from PNW belonging to the PN lineage originated from different wine grape cultivars (Pinot Noir, Cabernet Sauvignon, and Merlot) planted in three geographically separate vineyard blocks. Similarly, GLRaV-2-RG isolates obtained from cvs. Pinot Noir and Chardonnay planted in two separate vineyard blocks were highly similar. A possible explana-

TABLE 1. Range of coat protein (upper diagonal) and 70-kDa heat-shock protein homolog (lower diagonal) nucleotide sequence identities between different lineages of Grapevine leafroll-associated virus 2

\begin{tabular}{|c|c|c|c|c|c|c|}
\hline \multirow[b]{2}{*}{ Lineage } & \multicolumn{6}{|c|}{ Range $(\%)$} \\
\hline & $\mathrm{PN}$ & $93 / 955$ & $\mathrm{H} 4$ & PV20 & $\mathrm{BD}$ & $\mathrm{RG}$ \\
\hline $\mathrm{PN}$ & $\ldots$ & $91-92$ & $86-90$ & $72-74$ & $74-76$ & $76-78$ \\
\hline $93 / 955$ & 86-88 & $\ldots$ & 87-90 & $72-74$ & 77 & $76-78$ \\
\hline $\mathrm{H} 4$ & $83-88$ & $84-86$ & $\ldots$ & $72-75$ & $76-78$ & $76-78$ \\
\hline PV20 & $72-76$ & $76-77$ & $73-76$ & $\ldots$ & 71 & $71-73$ \\
\hline $\mathrm{BD}$ & $71-75$ & $72-74$ & $72-76$ & $71-74$ & $\ldots$ & $78-79$ \\
\hline $\mathrm{RG}$ & $69-73$ & $70-72$ & $70-73$ & $68-72$ & $78-80$ & $\ldots$ \\
\hline
\end{tabular}

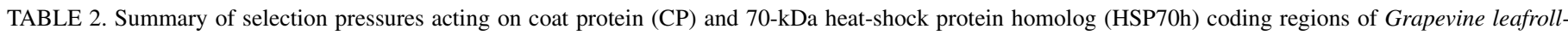
associated virus $2^{\mathrm{a}}$

\begin{tabular}{|c|c|c|c|c|c|c|}
\hline \multirow[b]{2}{*}{ Gene $^{b}$} & \multicolumn{2}{|c|}{ Global $d_{N} / d_{S}{ }^{\mathrm{c}}$} & \multicolumn{2}{|c|}{ Positively selected sites ${ }^{d}$} & \multicolumn{2}{|c|}{ Negatively selected sites ${ }^{\mathrm{d}}$} \\
\hline & $\log (\mathrm{L})$ & Mean & $N$ & Percent & $N$ & Percent \\
\hline $\mathrm{CP}$ & $-3,257.18$ & 0.081 & 0 & 0 & 138 & 69.7 \\
\hline HSP70h & $-1,769.15$ & 0.873 & 4 & 3.6 & 3 & 2.7 \\
\hline
\end{tabular}

a Global $d_{N} / d_{S}$ ratios and numbers of positively and negatively selected sites in CP and HSP70h data sets are shown in Supplementary Tables 3 and 4.

${ }^{\mathrm{b}}$ Data sets are represented by complete CP (198 codons) and partial HSP70h (110 codons) gene sequences.

${ }^{\mathrm{c}}$ Rate ratios: $d_{\mathrm{N}} / d_{\mathrm{S}}<1$ indicates purifying selection, $d_{N} / d_{S}=1$ suggests neutral selection, and $d_{N} / d_{S}>1$ indicates positive selection.

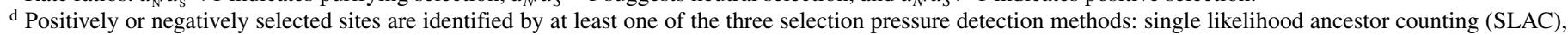
fixed effects likelihood (FEL), and random effects likelihood (REL). SLAC is a counting method while FEL and REL are both likelihood methods. 
tion for the presence of GLRaV-2 isolates with highly similar sequences in different wine grape cultivars planted in distinct geographical locations is that the initial source of cuttings of these wine grape cultivars were derived from scion materials grafted onto common rootstocks infected with isolates belonging to either PN or RG lineages. Conversely, the presence of GLRaV-2 isolates with divergent genome sequences belonging to the PN and $\mathrm{H} 4$ lineages in a single cultivar (cv. Cabernet Sauvignon) planted in the same vineyard block could be due to the block being planted with grapevines from two different sources, each carrying a distinct variant of GLRaV-2. Furthermore, the lack of any clustering of GLRaV-2-infected grapevines in these blocks and the absence of mixed infection of isolates belonging to PN and $\mathrm{H} 4$ lineages in a single grapevine reinforces the lack of within-field spread of GLRaV-2.
GLRaV-2 is unique among closteroviruses infecting grapevines because of its taxonomic affinity to members of the genus Closterovirus rather than the genus Ampelovirus (21). In the case of vector-transmitted members of the genus Closterovirus such as Citrus tristeza virus (CTV), the mode of virus transmission has been correlated with genetic diversity dynamics (40). Because viruses differ in selection pressure depending on their mode of transmission (10), understanding the selection forces, in the absence of a biological vector, acting on different genes of GLRaV2 in a vegetatively propagated perennial plant is of great interest. Therefore, we analyzed functional constraints on the evolution of the entire $\mathrm{CP}$ and a portion of HSP70h by determining the ratio of genetic diversity at nonsynonymous and synonymous sites. Our selective pressure analyses (Table 2) indicate that, overall, the CP and HSP70h are under strong selection pressure to preserve the
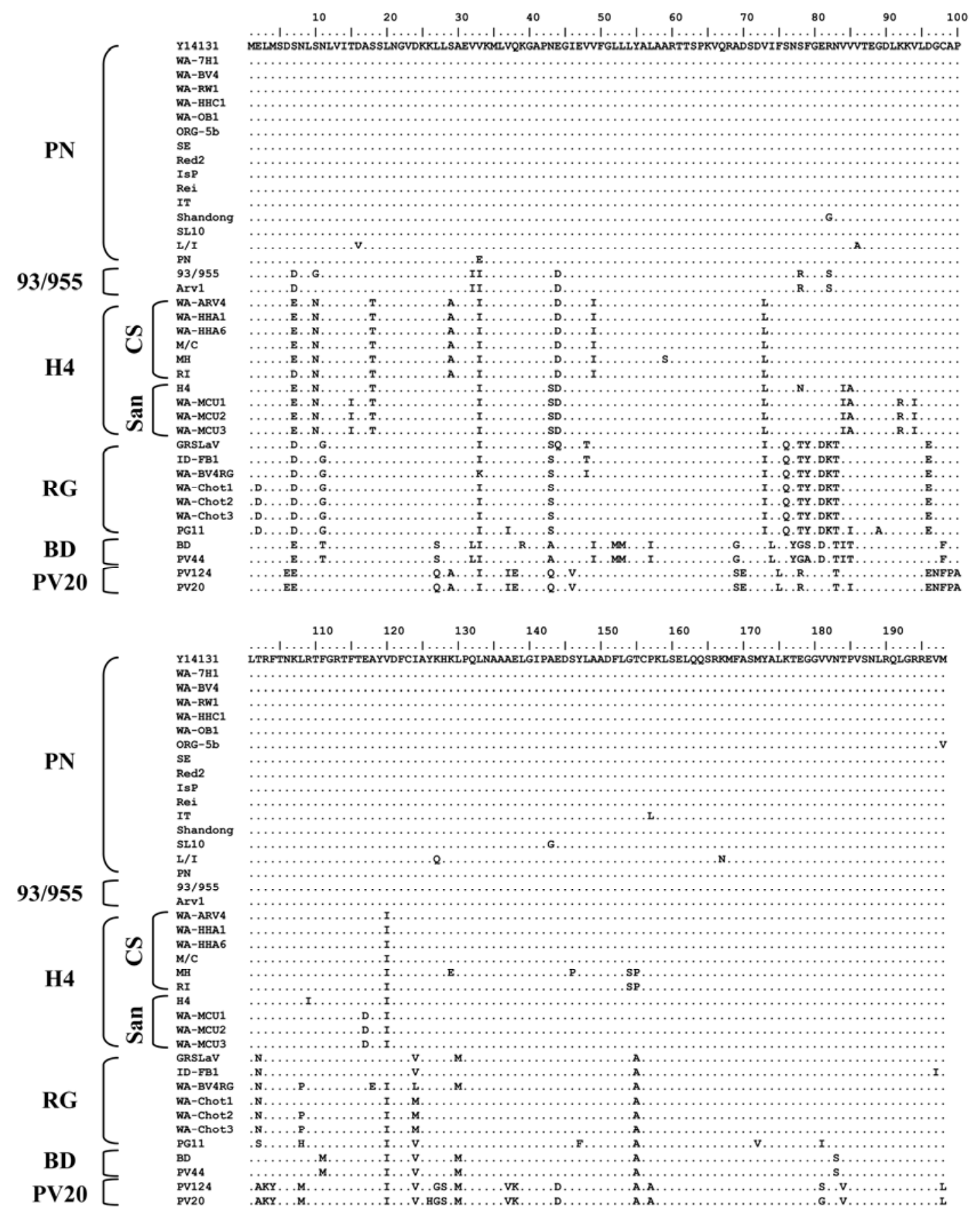

Fig. 4. Alignment of 39 coat protein (CP) gene amino acid sequences of Grapevine leafroll-associated virus 2 (GLRaV-2) isolates. A GLRaV-2 isolate from Italy (accession number Y14131) belonging to the 'PN' lineage was used as a reference to show differences in amino acids in each sequence. Identical residues in all sequences are indicated by dots. Names of isolates and their lineages are shown on the left. 
amino acid sequences encoded by these two genes. Although the mean $d_{N} / d_{S}$ ratio of 0.081 for the CP and 0.873 for the HSP70h was $<1.0$, it was 10.8 times lower for the $\mathrm{CP}$, suggesting that the $\mathrm{CP}$ is under stronger purifying selective pressure. This conclusion is supported further by an abundance of negatively selected codon sites in the CP. Although a similar bias toward purifying selection has been detected in the capsid region of several insecttransmitted viruses $(10,41)$, the lack of a biological vector for GLRaV-2 transmission would rule out such a constraint operating on the CP. It may be that the $\mathrm{CP}$ of $\mathrm{GLRaV}-2$ is subjected to structural constraints related to virion formation in addition to its other biological functions in virus replication and movement and, hence, is less tolerant to changes that could affect its functional integrity. In contrast, the comparatively higher $d_{N} / d_{S}$ ratio for HSP70h would suggest that this protein is relatively flexible to accommodate nonsynonymous changes and the positively selected sites may play an important role in the adaptive evolution of the gene.

Some of the GLRaV-2 isolates can be differentiated on herbaceous indicator hosts (17). However, the virus is transmitted mechanically with difficulty, making biological assays unreliable for the detection of GLRaV-2. The similarity of GLRD symptoms in grapevines infected with isolates belonging to PN, H4, and RG lineages underscores the need for using sensitive diagnostic assays to discriminate the three groups of isolates described in this study. Our ELISA results indicated that currently available antibodies from one of the commercial sources are unable to detect GLRaV-2-RG reliably, thereby limiting antibody-based diagnosis of all GLRaV-2 isolates documented in this study. A similar discrepancy in ELISA-based diagnosis of GLRaV-2 isolates was observed with different sources of commercially available antibodies (6). The serological variations observed could be due, at least in part, to variability of $\mathrm{CP}$ amino acid sequences of GLRaV-2 isolates examined in this study (Fig. 4). Further studies on epitope mapping of the CP may enhance development of serological assays for discriminating GLRaV-2 isolates and to detect all variants of GLRaV-2. Such approaches have been used recently for accurate comparison of biologically distinct CTV isolates $(3,35)$. In the short term, the RT-PCR-RFLP assay developed in this study (Fig. 5) is more practical in discriminating all GLRaV-2 isolates documented to date in PNW vineyards than is possible by serological assays. These markers also have the potential to track virus lineages in time and space for gaining more insights into the epidemiology of GLRD in the PNW vineyards. Because various isolates of GLRaV-2 are often associated with graft union incompatibility and such conditions may not be apparent in own-rooted grapevines, the RT-PCR-RFLP markers offer a practical and convenient method to diagnose distinct variants of GLRaV-2 in grapevine certification programs.

In addition to providing comprehensive information on genetic heterogeneity of GLRaV-2 sequences in two genomic regions, our study also offers a candidate framework of nomenclature of different lineages to facilitate "common language" among the scientific community working on grapevines to avoid perpetuation of unambiguous and misleading reports. Phylogenetic separation of GLRaV-2 isolates into six lineages was supported by similar topology of the phylogenetic trees derived from two genomic regions (CP and HSP70h) with high bootstrap support $(>70)$ at relevant nodes. Because this nomenclature of lineages covers all known isolates of GLRaV-2, such a classification would facilitate future comparative studies on diversity, epidemiology, and evolution of the virus. However, this study did not address genetic diversity thresholds between the six lineages to define species boundaries. Although Meng et al. (31) considered Grapevine rootstock stem lesion-associated virus (designated as $\mathrm{RG}$ in this study) to be a distinct strain of GLRaV-2, the species demarcation criteria for closteroviruses (29) would suggest that it should be considered as a separate species. Similarly, the extent of nucleotide identity values in $\mathrm{CP}$ and $\mathrm{HSP} 70 \mathrm{~h}$ sequences between some lineages (Table 1) fall outside the $10 \%$ identity range, such that isolates in PV20 and BD lineages may be considered as distinct species rather than strains of GLRaV-2. Due to practical difficulties in meeting the challenging criteria for species demarcation in the family Closteroviridae set up by the International Committee on Taxonomy of Viruses (29), alternative approaches are required to establish a logical framework for taxonomic separation of GLRaV-2 variants as distinct species or strains. We propose that Grapevine leafroll-associated virus 2 could be retained as a species, with six distinct GLRaV-2 strains with the suffix -PN, -93/955, -H4, -RG, -BD, and -PV20, each representing one lineage. This approach also offers flexibility for future revisions when "new" GLRaV-2 isolates are described.

In summary, genetically distinct isolates of GLRaV-2 exist in PNW vineyards as a consequence of introduction and subsequent dissemination of infected grapevine cuttings. The global diversity analysis and estimates of diversifying selective pressure revealed

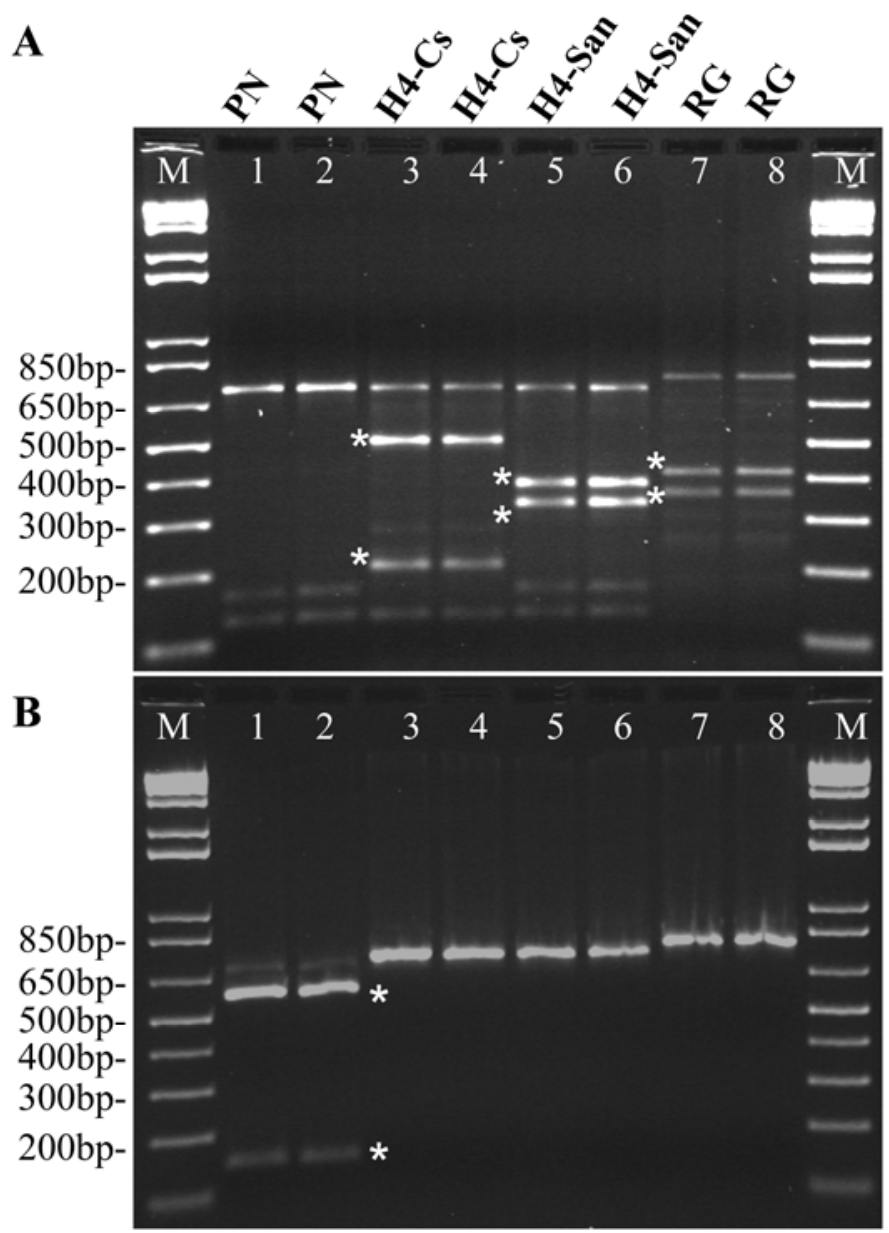

Fig. 5. Reverse-transcription polymerase chain reaction (RT-PCR)-restriction fragment length polymorphism analysis of coat protein (CP) fragments of Grapevine leafroll-associated virus 2 (GLRaV-2) isolates from 'PN', 'H4', and 'RG' lineages. DNA fragments were digested with restriction enzymes $\mathbf{A}$, Sau3A1 and B, HindIII and resolved on 1.8\% agarose gel. Two GLRaV-2 isolates each from PN (lanes 1 and 2) and H4 lineages (lanes 3 to 6) were amplified with primer pair V2dCPf 2 and CP96R and two isolates from the RG lineage (lanes 7 and 8) were amplified with primer pair V2dCPf2 and RGp19r2. DNA from isolates in the H4 lineage showed two patterns, corresponding to H4-Cs sublineage (lanes 3 and 4) and H4-San sublineage (lanes 5 and 6). Lane $M$ shows 1-kb-plus DNA marker (Invitrogen) for estimating the size of amplified DNA fragment. Size of marker DNA bands is indicated to the left. The products of restriction digestion are indicated by an asterisk. A, Top band in each sample lane is the original PCR product representing DNA undigested by the restriction enzyme Sau3A1. 
contrasting patterns of evolution in two viral genes with distinct functions and provided a foundation for further studies in understanding genetic diversity and evolution of GLRaV-2. The information provided in this study extends our current knowledge of the spectrum of global genetic diversity of GLRaV-2 isolates that can be used as a base line for making sequence comparisons of the entire genome of representative isolates of GLRaV-2 belonging to different lineages and developing a robust framework for classification of genetically distinct variants of GLRaV2. From a practical point of view, the RT-PCR-RFLP assay described in this study will offer a rapid molecular typing approach for the detection and discrimination of GLRaV-2 isolates that might escape antibody detection in clean plant programs.

\section{ACKNOWLEDGMENTS}

This work was supported, in part, by Washington State University's College of Agricultural, Human, and Natural Resource Sciences (CAHNRS) Agricultural Research Center and Extension Team-based internal competitive grant, the Washington Wine Commission's Wine Advisory Committee, the United States Department of Agriculture (USDA)-Agricultural Research Service Northwest Center for Small Fruits Research, USDA-Cooperative State Research, Education, and Extension Service Viticulture Consortium-West, and USDA-NIFA Specialty Crop Research Initiative award No. 2009-51181-06027. PPNS no. 0531, Department of Plant Pathology, CAHNRS, Agricultural Research Center Project No. WNPO 0616, Washington State University, Pullman.

\section{LITERATURE CITED}

1. Abou Ghanem-Sabanadzovic, N., Sabanadzovic, S., Castellano, M. A., Boscia, D., and Martelli, G. P. 2000. Properties of a new isolate of Grapevine leafroll-associated virus 2. Vitis 39:119-121.

2. Alabi, O. J., Martin, R. R., and Naidu, R. A. 2010. Sequence diversity, population genetics and potential recombination events in Grapevine rupestris stem pitting-associated virus in Pacific North-West vineyards. J. Gen. Virol. 91:265-276.

3. Albiach-Martí, M. R., Guerri, J., Cambra, M., Garnsey, S. M., and Moreno, P. 2000. Differentiation of Citrus tristeza virus isolates by serological analysis of p25 coat protein peptide maps. J. Virol. Methods 88:25-34.

4. Angelini, E., Bertazzon, N., and Borgo M., 2003. Occurrence of the Redglobe strain of Grapevine leafroll-associated virus 2 in table and wine grape varieties in Italy. Vitis 42:203-204.

5. Angelini, E., Bertazzon, N., and Borgo, M. 2004. Diversity among Grapevine leafroll-associated virus 2 isolates detected by heteroduplex mobility assay. J. Phytopathol 152:416-422.

6. Bertazzon, N., and Angelini, E. 2004. Advances in the detection of Grapevine leafroll-associated virus 2 variants. J. Plant Pathol. 86:283290.

7. Bertazzon, N., Angelini, E., and Borgo, M. 2006. Characterization of Grapevine leafroll-associated virus 2 strain BD. Pages 22-24 in: Extended Abstr. 15th Meet. ICVG. Stellenbosch, South Africa.

8. Beuve, M., Sempé, L., and Lemaire, O. 2007. A sensitive one-step realtime RT-PCR method for detecting Grapevine leafroll-associated virus 2 variants in grapevine. J. Virol. Methods 141:117-124.

9. Bonfiglioli, R., Edwards, F., Hoskins, N., and Pantaleo, A. 2003. Graft incompatibility syndrome in New Zealand Merlot vines involves another possible variant of GLRaV-2. Aust. N. Z. Grapegrower Winemaker 476:50-54.

10. Chare, E. R., and Holmes, E. C. 2004. Selection pressures in the capsid genes of plant RNA viruses reflect mode of transmission. J. Gen. Virol. 85:3149-3157.

11. Dolja, V. V. 2009. New developments in understanding gene functions and evolution of the grapevine closteroviruses. Pages 29-31 in: Extended Abstr. 16th Meet. ICVG. Dijon, France.

12. Fauquet, C., Mayo, M. A., Maniloff, J., Desselberger, U., and Ball, L. A. 2005. Virus Taxonomy: VIIIth Report of the International Committee on Taxonomy of Viruses. Elsevier Academic Press, San Diego, CA.

13. Fuchs, M., Martinson, T. E., Loeb, G. M., and Hoch, H. C. 2009. Survey for the three major leafroll disease-associated viruses in Finger Lakes vineyards in New York. Plant Dis. 93:395-401.

14. Goheen, A. C., Herman, F. N., and Weinberger, J. H. 1958. Leafroll (White Emperor disease) of grapes in California. Phytopathology 48: 51-54.
15. Golino, D. A., Sim, S., and Rowhani, A. 2000. Identification of the latent viruses associated with young vine decline in California. Pages 85-86 in: Extended Abstr. 13th Meet. ICVG. Adelaide, Australia.

16. Golino, D. A., Sim, S. T., Gill, R., and Rowhani, A. 2002. California mealybugs can spread grapevine leafroll disease. Calif. Agric. 56:196-201.

17. Goszczynski, D. E., Kasdorf, G. G. F., Pietersen, G., and van Tonder H., 1996. Detection of two strains of Grapevine leafroll-associated virus 2. Vitis 35:133-135.

18. Greif, C., Garau, R., Boscia, D., Prota, V. A., Fiori, M., Bass, P., Walter, B., and Prota, U., 1995. The relationship of grapevine leafroll-associated closterovirus 2 with a graft incompatibility condition of grapevines. Phytopathol. Mediterr. 34:167-173.

19. Gugerli, P. 2003. Grapevine leafroll and related viruses. Pages 25-31 in: Extended Abstr. 14th Meet. ICVG. Locorotondo, Italy.

20. Gugerli, P., Brugger, J. J., and Bovey, R. 1984. L'enroulement de la vigne: mise en évidence de particules virales et développement d'une méthode immuno-enzymatique pour le diagnostic rapide. Rev. Suisse Vitic. Arboric. Hortic. 16:299-304

21. Karasev, A. V. 2000. Genetic diversity and evolution of closteroviruses. Annu. Rev. Phytopathol. 38:293-324.

22. Kosakovsky Pond, S. L., and Frost, S. D. W. 2005. Datamonkey: Rapid detection of selective pressure on individual sites of codon alignments. Bioinformatics 21:2531-2533.

23. Kumar, S., Dudley, J., Nei, M., and Tamura, K. 2008. MEGA: A biologistcentric software for evolutionary analysis of DNA and protein sequences. Brief. Bioinf. 9:299-306.

24. Liu, Y. P., Peremyslov, V. V., Medina, V., and Dolja, V. V. 2009. Tandem leader proteases of Grapevine leafroll-associated virus 2: Host-specific functions in the infection cycle. Virology 383:291-299.

25. Maliogka, V. I., Dovas, C. I., Lotos, L., Efthimiou, K., and Katis, N. I.. 2009. Complete genome analysis and immunodetection of a member of a novel virus species belonging to the genus Ampelovirus. Arch. Virol. 154:209-218.

26. Maree, H. J., Freeborough, M.-J., and Burger, J. T. 2008. Complete nucleotide sequence of a South African isolate of Grapevine leafrollassociated virus 3 reveals a 5' UTR of 737 nucleotides. Arch. Virol. 153:755-757.

27. Martelli, G. P. 2000. Major graft-transmissible diseases of grapevines: Nature, diagnosis, and sanitation. Pages 231-236 in: Proc. 50th Anniversary Annu. Meet. ASEV. Seattle.

28. Martelli, G. P. 2009. Grapevine virology highlights 2006-2009. Pages 1523 in: Extended Abstr. 16th Meet. ICVG. Dijon, France.

29. Martelli, G. P., Agranovsky, A. A., Bar-Joseph, M., Boscia, D., Candresse, T., Coutts, R. H. A., Dolja, V. V., Falk, B. W., Gonsalves, D., Jelkmann, W., Karasev, A. V., Minafra, A., Namba, S., Vetten, H. J., Wisler, G. C., and Yoshikawa, N. 2005. Family Closteroviridae. Pages 1077-1087 in: Virus Taxonomy. Eighth Report of the International Committee on Taxonomy of Viruses. C. M. Fauquet, M. A. Mayo, J. Maniloff, U. Desselberger, and L. A. Ball, eds. Elsevier, Amsterdam.

30. Martin, R. R., Eastwell, K. C., Wagner, A., Lamprecht, S., and Tzanetakis, I. E. 2005. Survey for viruses of grapevine in Oregon and Washington. Plant Dis. 89:763-766.

31. Meng, B. Z., Li, C. H., Goszczynski, D. E., and Gonsalves, D. 2005. Genome sequences and structures of two biologically distinct strains of Grapevine leafroll-associated virus 2 and sequence analysis. Virus Genes 31:31-41.

32. Naidu, R. A., Soule, M. J., and Jarugula, S. 2006. Single and mixed infections of Grapevine leafroll-associated viruses in Washington State vineyards. (Abstr.) Phytopathology 96:S83.

33. Osman, F., Leutenegger, C., Golino, D., and Rowhani, A. 2007. Real-time RT-PCR (TaqMan) assays for the detection of Grapevine leafroll associated viruses 1-5 and 9. J. Virol. Methods 141:22-29.

34. Osman, F., Leutenegger, C., Golino, D., and Rowhani, A. 2008. Comparison of low-density arrays, RT-PCR and real-time TaqMan RTPCR in detection of grapevine viruses. J. Virol. Methods 149:292-299.

35. Peroni, L. A., Lorencini, M., Ribeiro dos Reis, J. R., Machado, M. A., and Stach-Machado, D. R. 2009. Differential diagnosis of Brazilian strains of Citrus tristeza virus by epitope mapping of coat protein using monoclonal antibodies. Virus Res. 145:18-25.

36. Prosser, S. W., Goszczynski, D. E., and Meng, B. 2007. Molecular analysis of double-stranded RNAs reveals complex infection of grapevines with multiple viruses. Virus Res. 124:151-159.

37. Rayapati, A. N., O'Neil, S., and Walsh, D. 2008. Grapevine leafroll disease. WSU Ext. Bull. EB2027E. http://cru.cahe.wsu.edu/ CEPublications/eb2027e/eb2027e.pdf.

38. Rowhani, A., Zhang, Y. P., and Golino, D. A. 2002. Isolation and characterization of a new closterovirus from grapevine. (Abstr.) Phytopathology 92:S71.

39. Rowhani, A., Zhang Y. P., Golino D. A., and Uyemoto J. K. 2000. Isolation and partial characterization of two new viruses from grapevine. 
In: Extended Abstr. 13th Meet. ICVG. Adelaide, Australia.

40. Roy, A., and Brlansky, R. H. 2009. Population dynamics of a Florida Citrus tristeza virus isolate and aphid-transmitted subisolates: Identification of three genotypic groups and recombinants after aphid transmission. Phytopathology 99:1297-1306.

41. Rubio, L., Ayllón, M. A., Kong, P., Fernández, A., Polek, M., Guerri, J., Moreno, P., and Falk, B. W. 2001. Genetic variation of Citrus tristeza virus isolates from California and Spain: Evidence for mixed infections and recombination. J. Virol. 75:8054-8062.

42. Sforza, R., Boudon-Padieu, E., and Greif, C. 2003. New mealybug species vectoring Grapevine leafroll-associated viruses-1 and -3 (GLRaV-1 and -3). Eur. J. Plant Pathol. 109:975-981.

43. Turturo, C., Saldarelli, P., Yafeng, D., Digiaro, M., Minafra, A., Savino, V., and Martelli, G. P. 2005. Genetic variability and population structure of Grapevine leafroll-associated virus 3 isolates. J. Gen. Virol. 86:217224.
44. Uyemoto J. K., Rowhani A., Luvisi D., and Krag, C. R. 2001. New closterovirus in 'Redglobe' grape causes decline of grafted plants. Calif. Agric. 55:28-31.

45. Varsani, A., Shepherd, D. N., Monjane, A. L., Owor, B. E., Erdmann, J. B., Rybicki, E. P., Peterschmitt, M., Briddon, R. W., and Markham, P. G. 2008. Recombination, decreased host specificity and increased mobility may have driven the emergence of Maize streak virus as an agricultural pathogen. J. Gen. Virol. 89:2063-2074.

46. Xu, Z., Hong, N., Xing, B., and Wang, G. P. 2006. Partial molecular characterization of a Chinese isolate of Grapevine leafroll-associated virus 2 and production of antisera to recombinant viral protein. J. Plant Pathol. 88:89-94.

47. Zhu, H. Y., Ling, K. S., Goszczynski, D. E., McFerson, J. R., and Gonsalves, D. 1998. Nucleotide sequence and genome organization of Grapevine leafroll-associated virus 2 is similar to Beet yellow virus, the closterovirus type member. J. Gen. Virol. 79:1289-1298. 